\title{
The Susceptibility to Mental Health Problems in the Future as a Serious Effect of Bullying on Adolescent: A Systematic Review
}

\author{
Ferry Diana Karmilasari ${ }^{1}$, Indah Winarni ${ }^{2}$, Heni Dwi Windarwati ${ }^{3}$ \\ ${ }^{1}$ Magister Program of Nursing and Mental Health Specialization, Faculty of Medicine, \\ Brawijaya University, Malang, Indonesia \\ ${ }^{2,3}$ Faculty of Medicine, Brawijaya University, Malang, Indonesia \\ Email: ferrydikar@gmail.com
}

\begin{abstract}
Bullying was a type of action which performed repeatedly, from time to time which involved particular group or individual who had more power than the victim. This systematic review was aimed to identify the impacts of bullying to the mental health of adolescent. This systematic review was initiated from identifying scientific articles that have been published between 2015-2019 on five databases as PubMed, Clinical Key, Science Direct, ProQuest, and Springer Link. The search involved use of terms as effects, bullying, adolescent and mental health. Overall, from the result of searching, this research collected 26 articles which fitted to the inclusion criteria. The result of 26 articles were overall in quantitative research design. The long-term impact of bullying for the victim was a problem of mental health. The mental health problem which found on the victim of bullying as stress, depression and anxiety, idea of suicide, low selfesteem, withdrawal from social contact, loneliness and decrease of self-confidence. The findings showed that bullying could affect a long-term effect since the adolescent up to adult period.
\end{abstract}

Keywords: Effects, Bullying, Adolescent, Mental Health.

\section{A. INTRODUCTION}

Bullying is defined as an action which performed repeatedly, and done from time to time by particular individual or group who has more power and done deliberately to the victim to raise injury, insecurity, and discomfort feeling (Bhuyan \& Manjula, 2017; Kozasa, Oiji, Kiyota, Sawa, \& Kim, 2017). The bullying is composed of four types. The first type of bullying is physical bullying which is performed by hitting, kicking, or pushing (AlBuhairan et al., 2017; Cardoso, Szlyk, Goldbach, Swank, \& Zvolensky, 2018; Shayo \& Lawala, 2019). The second type of bullying is verbal bullying as tempting, mocking, abusing, intimidating, name calling, humiliating, and criticizing (AlBuhairan et al., 2017; Cardoso et al., 2018; Sigurdson, Undheim, Wallander, Lydersen, \& Sund, 2015). The third type of bullying is relational, this type of bullying is performed by manipulating a relation which covers to social excommunication, spreading rumors, expelling from particular group or being non-selective from particular activity (Al Buhairan et al., 2017; Cardoso et al., 2018; Sigurdson et al., 2015). The fourth type of bullying is performed through information and communication technology or cyber bullying (AlBuhairan et al., 2017; Bhuyan \& Manjula, 2017; Estévez, 
Estévez, Segura, \& Suárez, 2019; Shayo \& Lawala, 2019). The high rate of bullying incident can raise negative effects on mental health of adolescent. In some countries, the rate of bullying incident on adolescent is varied. In Australia, this incident 13\%, Asia in Finland region 10\%, Jordan 44,2\%, and United Arab Emirates 20,9\%. The prevalence of bullying on children and adolescent in region of Africa 21-61\% in South Africa, 78\% in Malawi, 59\% in Ghana, and 31\% in Egypt. While, in America, this bullying rate 30\% (AlBuhairan et al., 2017; Arhin, Asante, Kugbey, \& Oti-Boadi, 2019; Naveed, Waqas, Aedma, Afzaal, \& Majeed, 2019). This result indicates that there are still many cases of bullying in a number of continents or countries. The bullying in school is regarded as an action or behavior which violates rights of adolescent to acquire education and health. Being victim of bullying can deliver long-term negative effects on the growth and problem of mental health on the adolescent. The victim of bullying will have a number of problems as decrease of school attendance, decrease of academic achievement, dropout, anxiety and depression problem (Bhuyan \& Manjula, 2017; Shayo \& Lawala, 2019). The relation with friends of same age plays an important role in social and emotional development on children and adolescent phase (Fredrick \& Demaray, 2018). Therefore, the behavior of bullying which occurs and attacks on adolescent period can be a predictor to raise stress and mental health consequence that may harm the adolescent (Kaiser \& Malik, 2015). The effects of mental health on adolescent who become the bullying victim has become a trigger to form a mental health service which aims to prevent and promote mental health service in public environment and school environment. Thus, it is hoped to be able to reduce the effects of bullying incident (Le et al., 2019). This systematic review is arranged to identify the effects of bullying to mental health on adolescent phase.

\section{B. METHODS}

The databases in this research were PubMed, Clinical Key, Science Direct, ProQuest, and Springer Link. The search was done by inserting keywords "Effects", and "Bullying" and "Adolescent" and "Mental Health". This step was conducted in each database by exerting PRISMA guidance method in order to lead the arrangement of feasibility criteria and article search strategy. The first search resulted 64 articles from PubMed, 34 articles from Clinical Key, 1270 articles from Science Direct, and 3253 articles from ProQuest, and 695 articles from Springer Link. Based on the title and abstract observation, it showed that 9 articles from PubMed, 1 article from Clinical Key, 22 articles from Science Direct, 47 articles from ProQuest, and 11 articles from Springer Link were appropriate. From those 90 articles, the researcher found 10 articles which were similar among databases, then, it remained to 80 articles. After a series of selection and journal article choice step, the researcher made PRISMA flowchart which could be seen 
on figure 1. This result was then continued by exerting evaluation on whole article which would be discussed and analyzed on systematic review. Based on the analysis, the research has been done in several continents or countries. The continents were Europe (21\%) in regions of Spain, Norway, Turkey, and UK, Asia (53\%) in regions of Saudi, Japan, India, Myanmar, Pakistan, Sri Lanka, Sargodha, China, Vietnam, and South Korea, America (16\%) in regions of America, Canada, and California, Africa (10\%) in regions of Ghana and Tanzania. The articles that have been collected were then selected according to the inclusion and exclusion criteria which have been determined by the researcher. The articles would be included if the articles discussed about the effects of bullying to the mental health of adolescent, long-term effects of bullying on adolescent, and related studies needed which could use qualitative, quantitative, or mixed method that aimed to collect the data of bullying effects on mental health of adolescent. On the other hand, the articles would be excluded if the articles used language except English, not original research, abstract only, or without full text. Further, the articles would be valued critically by the researcher and other reviewers to determine the inclusion in this systematic review. 


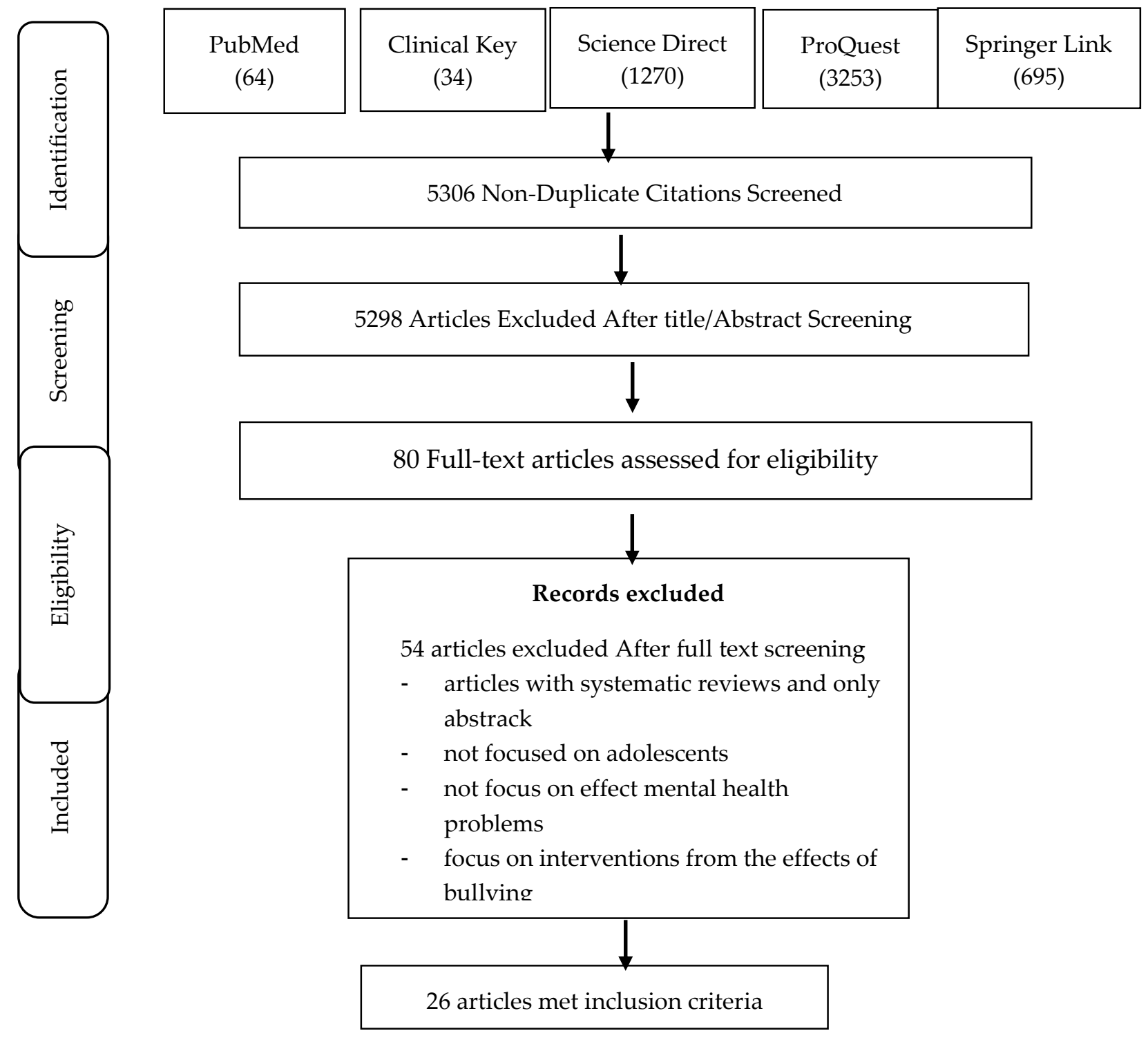

Figure 1 PRISMA Flowchart

Based on the question made by the research, "How is the effects of bullying to the mental health of adolescent?" the result of article searching on 5 databases showed a variety of data. There were several effects of bullying to the mental health of adolescent as these following:

\section{The Effects of Bullying on Mental Health of Adolescent}

On this step, the researcher would mention some effects that could raise because of bullying. The psychological pressure which impacted from bullying case could deliver effects on mental health of adolescent. The adolescence was the most period which determine individual in their life, since on this phase, the adolescent would face a number of problems, then, the adolescent was 
susceptible to undergo the possibility of mental health problems (Kaiser \& Malik, 2015). The researcher would display table 1 which illustrated the problems of mental health on adolescent who became the victim of bullying case.

Table 1. The Effects of Bullying on Mental Health Problem of Adolescent

\begin{tabular}{|c|c|}
\hline Effects of Mental Health & \multirow{9}{*}{$\begin{array}{l}\text { Supporting Articles } \\
\text { The mental health problem on adolescent who } \\
\text { experienced bullying could be identified from sadness, } \\
\text { behavior or suicide idea, low self-esteem, lack of } \\
\text { confidence, loneliness, and a few of friends (AlBuhairan } \\
\text { et al., 2017; Arhin et al., 2019). This research showed that } \\
\text { cyberbullying has a positive relation to the rise of stress, } \\
\text { depression, anxiety, and loneliness on adolescent (Cañas, } \\
\text { Estévez, Marzo, \& Piqueras, 2019), this was because the } \\
\text { cyberbullying tended to be instant, continuous, and have } \\
\text { broader reach than traditional bullying (Albdour, Hong, } \\
\text { Lewin, \& Yarandi, 2019). The bullying which was } \\
\text { performed by friend of same age could deliver mental } \\
\text { health effects on adolescent. The bullying that occurred } \\
\text { on childhood could be psychopathological risk and } \\
\text { emotional problem in the future (Chu, Fan, Lian, \& Zhou, } \\
\text { 2019). A number of researches have asserted a relation } \\
\text { between bullying that has been performed by friend of } \\
\text { same age and internalization problem on the adolescent } \\
\text { which could raise depression and social anxiety risks } \\
\text { (Kaiser \& Malik, 2015). }\end{array}$} \\
\hline Depression & \\
\hline Anxiety & \\
\hline Suicide Idea & \\
\hline Low Self-esteem & \\
\hline Lack of Confidence & \\
\hline Loneliness & \\
\hline Stress & \\
\hline Social Anxiety & \\
\hline
\end{tabular}

\section{DISCUSSION}

Bullying and mental health were important phenomena which could affect negatively on the mental well-being in adolescent circle(Nguyen, Nakamura, Seino, \& Al-Sobaihi, 2019). The literature has indicated that the bullying victim could have social health, psychosocial, and physical problems as suicide and loneliness or social isolation (Arhin et al., 2019; Shayo \& Lawala, 2019). The bullying was an action which often occurred in many cultures, races, social circumstances, school environment, workplace and home (Naveed et al., 2019). The high rate of bullying case in the adolescent was related to negative effects to the mental, social, and physical health of bullying victim. The effects of bullying to mental health as depression, discomfort feeling, stress, anxiety, suicide idea, lack of confidence, low self-esteem, and self-isolation (AlBuhairan et al., 2017; Arhin et al., 2019; Naveed et al., 2019). The bullying not only affected 
on mental health, but also affected negatively to the decrease of school attendance, decrease of academic achievement, and high risk of drugs misuse (Naveed et al., 2019).

The internalization indications which frequently occurred on bullying victim were depression, anxiety, fright, self-isolation from social contact. A research with longitudinal research showed that who have experienced bullying during adolescent phase would have increase of panic disorder or depression and anxiety disorder risks on the first phase. While, the externalization indications on bullying victim were reflected from attitude that pointed to other people like anger, tendency to do risky behavior, criminality, and aggressive behavior of individual to bully other people, those indications were more frequently appeared or indicated on adolescent who were involved in bullying incident than the adolescent who did not involve in bullying incident (Sigurdson et al., 2015). The research has been done in 42 countries in Europe and North America revealed that the victim of bullying tended to have low social economic status, difficult relationship, and mental disorder (Shayo \& Lawala, 2019).

The risk factor which affected them to be the victim of bullying were background of race, religion, lower economic status and health problem. Besides to those factors, the adolescent who were involved in internet use and media social could also enable them to be the victim or doer of bullying (Zhang et al., 2019). The bullying which found in cyberspace was increasing in recent time. This situation took place as the use of internet and cellular phone was increasing among adolescent. The increase of adolescent activity to use internet was not supported by social concern and attention. Thus, the bullying could occur in cyberspace which spread rapidly, time and location unlimited (Su et al., 2019).

The adolescent could form and build social circle in their surroundings. The adolescent who have many kinds of health problem, particularly psychological health problem would tend to create and build negative social environment. The characteristic of adolescent who have maladaptive personality and relation with bad friends of same age would increase interpersonal stressor, as bullying (Chu et al., 2019). Overall, the relation between bullying incident and mental health problem was reciprocal. The bullying was a factor which could impact to mental health problem, while the mental health problem could also turn the adolescent to be the victim of bullying (Le et al., 2019). The victim of bullying needed support from several parties in order to prevent the appearance of mental health problem in adult phase. Therefore, to prevent this phenomenon, it needed the parent engagement or involvement in every process of growth phase of adolescent and the importance to encourage them to have a good friendship and relationship with friends of same age (Murshid, 2017). 
Table 2. Table Discussed $(n=26)$

\begin{tabular}{|c|c|c|c|c|}
\hline No & Title and Authors & Research Methods & Sample & Result \\
\hline 1 & $\begin{array}{l}\text { The relationship of bullying and } \\
\text { physical violence to mental health and } \\
\text { academic performance: A cross- } \\
\text { sectional study among adolescents in } \\
\text { Kingdom of Saudi Arabia } \\
\text { (AlBuhairan et al., 2017) }\end{array}$ & $\begin{array}{l}\text { Desain: } \\
\text { Quantitative } \\
\text { Cross-sectional } \\
\text { Study }\end{array}$ & $\mathrm{N}=9073$ & $\begin{array}{l}\text { Exposure to physical violence and bullying were } \\
\text { both associated with higher odds of having more } \\
\text { frequent symptoms of depression and anxiety. } \\
\text { Those exposed to physical violence were at higher } \\
\text { odds of having poorer academic performance. }\end{array}$ \\
\hline 3 & $\begin{array}{l}\text { Relationship between the experience } \\
\text { of being a bully/victim and mental } \\
\text { health in a preadolescence } \\
\text { and adolescence: a cross-sectional } \\
\text { study } \\
\text { (Kozasa et al., 2017) }\end{array}$ & $\begin{array}{c}\text { Desain: } \\
\text { Quantitative } \\
\text { Cross-sectional } \\
\text { Study }\end{array}$ & $\mathrm{N}=824$ & $\begin{array}{l}\text { The relationship between the experience of being } \\
\text { a bully/victim and mental health, both } \\
\text { preadolescents and adolescents of the "Victim } \\
\text { Only" group had significantly higher scores on the } \\
\text { YSR's internal- izing problems compared with the } \\
\text { "Neither" group. Risks of suicidal ideation were } \\
\text { significantly higher in the "Victim and Bully" } \\
\text { group than in the "Neither" group. }\end{array}$ \\
\hline 4 & $\begin{array}{l}\text { General and Ethnic-Biased Bullying } \\
\text { Among Latino Students: Exploring }\end{array}$ & $\begin{array}{c}\text { Desain: } \\
\text { Quantitative }\end{array}$ & $\mathrm{N}=534$ & $\begin{array}{l}\text { Ethnic-biased and verbal or relational bullying had } \\
\text { a direct effect on depression. }\end{array}$ \\
\hline
\end{tabular}




\begin{tabular}{|c|c|c|c|c|}
\hline & $\begin{array}{l}\text { Risks of Depression, Suicidal Ideation, } \\
\text { and Substance Use } \\
\text { (Cardoso et al., 2018) }\end{array}$ & $\begin{array}{c}\text { Cross-sectional } \\
\text { Study }\end{array}$ & & \\
\hline 5 & $\begin{array}{l}\text { Experiences of Bullying in Relation to } \\
\text { Psychological Functioning of Young } \\
\text { Adults: An Exploratory Study } \\
\text { (Bhuyan \& Manjula, 2017) }\end{array}$ & $\begin{array}{c}\text { Exploratory } \\
\text { Research Design. }\end{array}$ & $\mathrm{N}=311$ & $\begin{array}{l}\text { Findings suggest that people with bullying } \\
\text { experiences tend to have more psychological } \\
\text { problems compared to people who had no } \\
\text { experiences of bullying. }\end{array}$ \\
\hline 6 & $\begin{array}{l}\text { Does bullying predict suicidal behaviors } \\
\text { among in-school adolescents? A cross- } \\
\text { sectional finding from Tanzania as an } \\
\text { example of a low-income country } \\
\text { (Shayo \& Lawala, 2019) }\end{array}$ & $\begin{array}{l}\text { Desain: } \\
\text { Quantitative } \\
\text { Cross-sectional } \\
\text { Study }\end{array}$ & $\mathrm{N}=3739$ & $\begin{array}{l}\text { Being bullied was independently associated with } \\
\text { suicidal ideation and suicide attempt. Bullying is } \\
\text { prevalent and possibly a potential predictor of } \\
\text { suicidal behaviors among in-school adolescents in } \\
\text { Tanzania. }\end{array}$ \\
\hline 7 & $\begin{array}{l}\text { Peer Victimization and Suicidal } \\
\text { Thoughts and Behaviors in Depressed } \\
\text { Adolescents } \\
\text { (Stewart, Valeri, Esposito, \& Auerbach, } \\
2018)\end{array}$ & $\begin{array}{c}\text { Desain: } \\
\text { Quantitative }\end{array}$ & $\mathrm{N}=340$ & $\begin{array}{l}\text { Sex differences revealed that this effect only held } \\
\text { for males whereas bullying was directly associated } \\
\text { with suicide attempts among females. In contrast, } \\
\text { overt and relational bullying were nonlinearly } \\
\text { associated with suicide plans }\end{array}$ \\
\hline 8 & $\begin{array}{l}\text { Internal resilience, peer victimization, } \\
\text { and suicidal ideation among } \\
\text { adolescents } \\
\text { (Hirschtritt, Ordóñez, Rico, \& Lewinn, } \\
\text { 2015) }\end{array}$ & $\begin{array}{l}\text { Desain: } \\
\text { Quantitative } \\
\text { Cross-sectional } \\
\text { Study }\end{array}$ & $\mathrm{N}=42.594$ & $\begin{array}{l}\text { Peer Victimization was associated with increased } \\
\text { odds of suicidal ideation compared with no Peer } \\
\text { Victimization. }\end{array}$ \\
\hline 9 & $\begin{array}{l}\text { Self-esteem and social interaction } \\
\text { anxiety in cyberbullied adolescents } \\
\text { (Fernandes, Sanyal, \& Chadha, 2015) }\end{array}$ & $\begin{array}{c}\text { Desain: } \\
\text { Quantitative }\end{array}$ & $\mathrm{N}=480$ & $\begin{array}{l}\text { - The findings revealed that the non-cyberbullied } \\
\text { adolescents had significantly higher self-esteem } \\
\text { than the cyberbullied adolescents, and the }\end{array}$ \\
\hline
\end{tabular}


cyberbullied adolescents had significantly higher levels of social interaction anxiety than the non-cyberbullied adolescents.

- Furthermore, the study reported that the cyberbullied boys had significantly higher selfesteem than the cyberbullied girls.

\begin{tabular}{|llccl}
$\mathbf{1 0}$ & $\begin{array}{l}\text { Psychological adjustment in } \\
\text { cybervictims and cyberbullies in } \\
\text { secondary education } \\
\text { (Cañas et al., 2019) }\end{array}$ & $\begin{array}{c}\text { Desain: } \\
\text { Quantitative }\end{array}$ & $\mathrm{N}=1318 \begin{array}{l}\text { Severe cybervictims and cyberbullies showed } \\
\text { higher scores in perceived stress, loneliness, } \\
\text { depression, and social anxiety, and lower scores in } \\
\text { self-concept, life satisfaction, and emotional } \\
\text { intelligence, in comparison with non-cybervictims } \\
\text { and non- cyberbullies. }\end{array}$ \\
\hline $\mathbf{1 1}$ & $\begin{array}{l}\text { Peer Victimization and Psychiatric } \\
\text { Symptoms among Adolescents }\end{array}$ & $\begin{array}{c}\text { Desain: } \\
\text { Quantitative }\end{array}$ & $\mathrm{N}=400$ & $\begin{array}{l}\text { Peer victimization showed strong association with } \\
\text { psychiatric symptoms among adolescents. }\end{array}$
\end{tabular}
(Kaiser \& Malik, 2015)

\begin{tabular}{ccccc}
\hline 12 & $\begin{array}{l}\text { The Influence of Bullying and } \\
\text { Cyberbullying in the Psychological } \\
\text { Adjustment of Victims and Aggressors } \\
\text { in Adolescence } \\
\text { (Estévez et al., 2019) }\end{array}$ & $\begin{array}{c}\text { Desain: } \\
\text { Quantitative }\end{array}$ & $\mathrm{N}=1318$ & $\begin{array}{l}\text { The results indicated that the victims generally } \\
\text { present greater maladjustment than the } \\
\text { aggressors. Both victims and cybervictims showed } \\
\text { a greater decrease in all the dimensions of self- } \\
\text { concept }\end{array}$ \\
\hline $\mathbf{1 3}$ & $\begin{array}{l}\text { The long-term effects of being bullied or } \\
\text { a bully in adolescence on externalizing } \\
\text { and internalizing mental health } \\
\text { problems in adulthood }\end{array}$ & $\begin{array}{c}\text { Desain: } \\
\text { Quantitative } \\
\text { Longitudinal } \\
\text { Study }\end{array}$ & $\mathrm{N}=2464$ & $\begin{array}{l}\text { - All groups involved in bullying in young } \\
\text { adolescence had adverse mental health } \\
\text { outcomes in adulthood compared to non- } \\
\text { involved. }\end{array}$
\end{tabular}
(Sigurdson et al., 2015) 
- Those being bullied were affected especially regarding increased total sum of depressive symptoms and high levels of total, internalizing and critical symptoms, increased risk of having received help for mental health problems, and reduced functioning because of a psychiatric problem in adulthood.

14 The Impact of Cyberbullying Desain: $\mathrm{N}=150$ - Thirty-four percent of adolescents reported
on Physical and Psychological Health of Arab American Adolescents

Quantitative

(Albdour et al., 2019)
Cross-sectional Study
15 Traditional and cyberbullying cooccurrence and its relationship to psychiatric symptoms

(Tural Hesapcioglu \& Ercan, 2017) cyberbullying victimization and $26.7 \%$ reported cyberbullying perpetration at least once in the past year.

- Perpetrators experienced more physical symptoms while victims experienced more psychological distress. Implications for future research are discussed.

- All subscale scores of bullying and victimization are significantly related to higher depression, anxiety, low self-esteem.

- For people who were exposed to cyberbullying in addition to traditional bullying, the severity of the psychiatric symptoms is significantly higher

\begin{tabular}{|c|c|c|c|c|}
\hline 16 & $\begin{array}{l}\text { Adult mental health consequences of } \\
\text { peer bullying and maltreatment in } \\
\text { childhood: two cohorts in two countries }\end{array}$ & $\begin{array}{c}\text { Desain: } \\
\text { Quantitative }\end{array}$ & $\mathrm{N}=5446$ & $\begin{array}{l}\text { Bullying victimization, maltreatment, and overall } \\
\text { mental health problems. Those who were both } \\
\text { maltreated and bullied were at increased risk for }\end{array}$ \\
\hline
\end{tabular}


(Lereya, Copeland, Costello, \& Wolke, Avon Longitudinal 2015)
Study
17 The indirect effect of bullying on adolescent self-rated health through mental health: A gender specific pattern (Zhang et al., 2019)

\section{Desain:}

Quantitative

Study Participants

Comprised

overall mental health problems, anxiety, and depression. Compared with children who were not maltreated or bullied, children who were only maltreated were at increased risk for depression in young adulthood.

Structural equation modeling analyses showed that, in addition to the main effect of bullying on adolescent's physical health, (based on joint significance test) mental health has an indirect effect on and gender moderates the relationship between bullying victimization and adolescents' self-rated health.

18 Does bullying victimization really influence adolescents' psychosocial problems? A three-wave longitudinal study in China

(Chu et al., 2019)

\section{Desain:}

Quantitative

A three-wave longitudinal study
$\mathrm{N}=661$

Bullying victimization did not predict adolescents' psychosocial problems. Instead, adolescents with psychosocial problems were more likely to experience bullying victimization. Depression and general anxiety were two common predictors of traditional bullying and cyberbullying victimization.

19 Bullying victimization and mental health outcomes of adolescents in Myanmar, Pakistan, and Sri Lanka (Murshid, 2017)

\section{Desain:}

Quantitative

Global School

Based Health
$\mathrm{N}=10.609$

Results indicate that adolescents who were bullied were significantly more likely to report symptoms of depression in all three countries.

Survey 


\begin{tabular}{llccc}
\hline 20 & Peer Victimization, Supportive & Desain: & $\mathrm{N}=1750$ \\
& Parenting, and Depression Among & Quantitative & \\
Adolescents in South Korea: A & Longitudinal & \\
Longitudinal Study & & Study & \\
(Hong \& Min, 2018) & & &
\end{tabular}

\begin{tabular}{|c|c|c|c|}
\hline 21 & $\begin{array}{l}\text { Peer victimization and suicidal } \\
\text { ideation: The role of gender and }\end{array}$ & $\begin{array}{c}\text { Desain: } \\
\text { Quantitative }\end{array}$ & $\mathrm{N}=403$ \\
\hline
\end{tabular}

(Fredrick \& Demaray, 2018)

\begin{tabular}{|c|c|c|c|c|}
\hline & & & & stronger for girls than boys. \\
\hline 23 & $\begin{array}{l}\text { Is involvement in school bullying } \\
\text { associated with increased risk of }\end{array}$ & $\begin{array}{c}\text { Desain: } \\
\text { Quantitative }\end{array}$ & $N=5726$ & $\begin{array}{l}\text { Each type of school bullying perpetration was } \\
\text { associated with murderous ideation and }\end{array}$ \\
\hline
\end{tabular}


murderous ideation and behaviours Research Project among adolescent students in China?

(Su et al., 2019)

"Adolescent

Health and Risk
Behaviours In

Anhui Province".

24 Victimization Experiences and Mental Health Outcomes Among Grades 7 to Students in Manitoba, Canada (Stewart-Tufescu, Salmon, Taillieu, Fortier, \& Afifi, 2019)
Desain:

Quantitative

Cross-sectional

Study behaviors, as was each type of bullying victimization. Students who experienced more types of school bullying perpetration and victimization were more likely to report murderous ideation and behaviors.

$\mathrm{N}=64.174 \quad$ Mental health outcomes included mental health
functioning and emotional well-being, and feelings of sadness and hopelessness. All nine victimization types were associated with increased odds of having moderate/languishing mental health functioning and emotional well-being and feeling sad and hopeless

25 Association of bullying experiences with depressive symptoms and psychosocial functioning among school going children and adolescents (Naveed et al., 2019)

26 Cyber and traditional bullying victimization as a risk factor for mental health problems and suicidal ideation in adolescents

(Bannink, Broeren, Van De Looij Jansen, De Waart, \& Raat, 2014)

Desain: $\quad \mathrm{N}=452$ Experience of victimization reported mild
Quantitative

Cross-sectional Study depressive symptoms, moderate, moderately severe and severe depressive symptoms. Both victims and perpetrators of bullying experienced adverse emotional and social consequences.

$\begin{array}{cll}\text { Desain: } & \mathrm{N}=3181 & \text { Traditional bullying victimization was associated } \\ \text { Quantitative } & & \text { with suicidal ideation, whereas cyber bullying } \\ \text { Longitudinal } & \text { victimization was not associated with suicidal } \\ \text { Study } & \text { ideation after controlling for baseline suicidal } \\ & \text { ideation. }\end{array}$




\section{CONCLUSION}

This systematic review has referred that bullying could impact mental health problem which could raise risk to develop the mental disorder possibility in adult or future phase. The importance of intervention which aimed to prevent bullying case was not only required in the school environment, but also in the social environment and social media. The intervention of bullying prevention was aimed to ensure that the environment was safe, healthy, and comfortable for the adolescent. In addition, the intervention program of bullying prevention in school was needed to do by preventing this bullying case to occur in school environment and handling on bullying victim and bullying performer or doer, in the hope that this case would not affect to mental health problem.

\section{REFERENCES}

1. Albdour, M., Hong, J. S., Lewin, L., \& Yarandi, H. (2019). The Impact of Cyberbullying on Physical and Psychological Health of Arab American Adolescents. Journal of Immigrant and Minority Health, 21(4), 706-715. https://doi.org/10.1007/s10903-018-00850-w

2. AlBuhairan, F., Abou Abbas, O., El Sayed, D., Badri, M., Alshahri, S., \& de Vries, N. (2017). The relationship of bullying and physical violence to mental health and academic performance: A cross-sectional study among adolescents in Kingdom of Saudi Arabia. International Journal of Pediatrics and Adolescent Medicine, 4(2), 61-65. https://doi.org/10.1016/j.ijpam.2016.12.005

3. Arhin, D. K., Asante, K. O., Kugbey, N., \& Oti-Boadi, M. (2019). The relationship between psychological distress and bullying victimisation among school-going adolescents in Ghana: A cross-sectional study. BMC Research Notes, 12(1), 1-6. https://doi.org/10.1186/s13104-019-4300-6

4. Bannink, R., Broeren, S., Van De Looij - Jansen, P. M., De Waart, F. G., \& Raat, H. (2014). Cyber and traditional bullying victimization as a risk factor for mental health problems and suicidal ideation in adolescents. PLoS ONE, 9(4), 11-16. https://doi.org/10.1371/journal.pone.0094026

5. Bhuyan, K., \& Manjula, M. (2017). Experiences of bullying in relation to psychological functioning of young adults: An exploratory study. Indian Journal of Social Psychiatry, 33(3), 240. https://doi.org/10.4103/0971-9962.214604

6. Cañas, E., Estévez, E., Marzo, J. C., \& Piqueras, J. A. (2019). Psychological adjustment in cybervictims and cyberbullies in secondary education. Anales de Psicologia, 35(3), 434-443. https://doi.org/10.6018/analesps.35.3.323151

7. Cardoso, J. B., Szlyk, H. S., Goldbach, J., Swank, P., \& Zvolensky, M. J. (2018). General and Ethnic-Biased Bullying Among Latino Students: Exploring Risks of Depression, Suicidal Ideation, and Substance Use. Journal of Immigrant and Minority Health, 20(4), 816-822. https://doi.org/10.1007/s10903-017-0593-5

8. Chu, X. W., Fan, C. Y., Lian, S. L., \& Zhou, Z. K. (2019). Does bullying 
victimization really influence adolescents' psychosocial problems? A threewave longitudinal study in China. Journal of Affective Disorders, 246(September 2018), 603-610. https://doi.org/10.1016/j.jad.2018.12.103

9. Estévez, E., Estévez, J. F., Segura, L., \& Suárez, C. (2019). The influence of bullying and cyberbullying in the psychological adjustment of victims and aggressors in adolescence. International Journal of Environmental Research and Public Health, 16(12). https://doi.org/10.3390/ijerph16122080

10. Fernandes, T., Sanyal, N., \& Chadha, S. (2015). Self-esteem and social interaction anxiety in cyberbullied adolescents - ProQuest. Indian Journal of Health and Wellbeing, 6(7), 648-655. Retrieved from http://search.proquest.com.proxy.cityu.edu/docview/1718296043?pqorigsite $=$ summon

11. Fredrick, S. S., \& Demaray, M. K. (2018). Peer victimization and suicidal ideation: The role of gender and depression in a school-based sample. Journal of School Psychology, 67(February), 1-15. https://doi.org/10.1016/j.jsp.2018.02.001

12. Hirschtritt, M. E., Ordóñez, A. E., Rico, Y. C., \& Lewinn, K. Z. (2015). Internal resilience, peer victimization, and suicidal ideation among adolescents. International Journal of Adolescent Medicine and Health, 27(4), 415-423. https://doi.org/10.1515/ijamh-2014-0060

13. Hong, H. C., \& Min, A. (2018). Peer Victimization, Supportive Parenting, and Depression Among Adolescents in South Korea: A Longitudinal Study. Journal of Pediatric Nursing, 43, e100-e105. https://doi.org/10.1016/j.pedn.2018.08.002

14. Kaiser, A., \& Malik, S. (2015). Peer Victimization and Psychiatric Symptoms among Adolescents. Pakistan Journal of Medical Research, 54(4), 113-116.

15. Kozasa, S., Oiji, A., Kiyota, A., Sawa, T., \& Kim, S. yung. (2017). Relationship between the experience of being a bully/victim and mental health in preadolescence and adolescence: A cross-sectional study. Annals of General Psychiatry, 16(1), 1-11. https://doi.org/10.1186/s12991-017-0160-4

16. Le, H. T. H., Tran, N., Campbell, M. A., Gatton, M. L., Nguyen, H. T., \& Dunne, M. P. (2019). Mental health problems both precede and follow bullying among adolescents and the effects differ by gender: A cross-lagged panel analysis of school-based longitudinal data in Vietnam. International Journal of Mental Health Systems, 13(1), 1-10. https://doi.org/10.1186/s13033019-0291-x

17. Lereya, S. T., Copeland, W. E., Costello, E. J., \& Wolke, D. (2015). Adult mental health consequences of peer bullying and maltreatment in childhood: Two cohorts in two countries. The Lancet Psychiatry, 2(6), 524-531. https://doi.org/10.1016/S2215-0366(15)00165-0

18. Murshid, N. S. (2017). Bullying victimization and mental health outcomes of 
adolescents in Myanmar, Pakistan, and Sri Lanka. Children and Youth Services Review, 76, 163-169. https://doi.org/10.1016/j.childyouth.2017.03.003

19. Naveed, S., Waqas, A., Aedma, K. K., Afzaal, T., \& Majeed, M. H. (2019). Association of bullying experiences with depressive symptoms and psychosocial functioning among school going children and adolescents. BMC Research Notes, 12(1), 10-13. https://doi.org/10.1186/s13104-019-4236-x

20. Nguyen, H. T. L., Nakamura, K., Seino, K., \& Al-Sobaihi, S. (2019). Impact of parent-adolescent bonding on school bullying and mental health in Vietnamese cultural setting: Evidence from the global school-based health survey. BMC Psychology, 7(1), 1-10. https://doi.org/10.1186/s40359-019-0294-z

21. Shayo, F. K., \& Lawala, P. S. (2019). Does bullying predict suicidal behaviors among in-school adolescents? A cross-sectional finding from Tanzania as an example of a low-income country. BMC Psychiatry, 19(1), 1-7. https://doi.org/10.1186/s12888-019-2402-2

22. Sigurdson, J. F., Undheim, A. M., Wallander, J. L., Lydersen, S., \& Sund, A. M. (2015). The long-term effects of being bullied or a bully in adolescence on externalizing and internalizing mental health problems in adulthood. Child and Adolescent Psychiatry and Mental Health, 9(1), 1-13. https://doi.org/10.1186/s13034-015-0075-2

23. Stewart-Tufescu, A., Salmon, S., Taillieu, T., Fortier, J., \& Afifi, T. O. (2019). Victimization Experiences and Mental Health Outcomes Among Grades 7 to 12 Students in Manitoba, Canada. International Journal of Bullying Prevention. https://doi.org/10.1007/s42380-019-00056-0

24. Stewart, J. G., Valeri, L., Esposito, E. C., \& Auerbach, R. P. (2018). Peer Victimization and Suicidal Thoughts and Behaviors in Depressed Adolescents. Journal of Abnormal Child Psychology, 46(3), 581-596. https://doi.org/10.1007/s10802-017-0304-7

25. Su, P. Y., Wang, G. F., He, H., Han, A. Z., Zhang, G. B., \& Xu, N. (2019). Is involvement in school bullying associated with increased risk of murderous ideation and behaviours among adolescent students in China? BMC Psychiatry, 19(1), 1-10. https://doi.org/10.1186/s12888-019-2108-5

26. Susanti, H., Lovell, K., \& Mairs, H. (2018). What does the literature suggest about what carers need from mental health services for their own wellbeing? A Systematic Review. Enfermeria Clinica, 28(February), 102-111. https://doi.org/10.1016/S1130-8621(18)30047-0

27. Tural Hesapcioglu, S., \& Ercan, F. (2017). Traditional and cyberbullying cooccurrence and its relationship to psychiatric symptoms. Pediatrics International, 59(1), 16-22. https://doi.org/10.1111/ped.13067

28. Zhang, A., Liu, C., Bornheimer, L. A., Solomon, P., Wang, K., \& Morrow, S. P. (2019). The indirect effect of bullying on adolescent self-rated health through mental health: A gender specific pattern. Children and Youth Services Review, 
International Journal of Science and Society, Volume 2, Issue 3, 2020

104(March). https://doi.org/10.1016/j.childyouth.2019.104385 